\title{
Infection with cytomegalovirus in homosexual men
}

\author{
R A COUTINHO,* $P$ WERTHEIM-VAN DILLEN, $+P$ ALBRECHT-van LENT,* \\ N NAGELKERKE, $\$$ H KUIPERS, $\S$ A VAN BENTUM-VAN HAAGEN,†T RIJSDIJK,* \\ AND J VAN DER NOORDAAT \\ From the *Municipal Health Service, the + Laboratorium voor de Gezondheidsleer, the $\neq$ Laboratory of \\ Medical Physics, and the §Bureau of Statistics, Amsterdam, The Netherlands
}

SUMMARY The prevalence and incidence of cytomegalovirus (CMV) infections were studied in a group of homosexual men. Of the 710 participants, $501(70 \cdot 6 \%)$ had complement fixing antibodies to CMV on entry to the study. During the follow up (maximum 23 months) $69 \mathrm{CMV}$ infections were found: 50 primary infections among the 209 seronegative men (attack rate $27 \cdot 3 \%$ ), and 19 recurrent infections among the 501 seropositive men (attack rate $6 \cdot 2 \%$ ).

The prevalence of antibody to CMV was correlated with four characteristics of the participants' lifestyles: duration of homosexual activity, number of different sexual partners, history of syphilis, and anal sexual contact. Among the seronegative men, the incidence of primary infection with CMV correlated with a history of syphilis and anal sexual contact.

We conclude that infections with CMV are highly prevalent among homosexual men, and that anal sexual contact plays an important part in the transmission of this virus.

\section{Introduction}

There is evidence that infections with cytomegalovirus (CMV) can be transmitted by sexual contact, especially among homosexual men. A study of male homosexuals in San Francisco found a very high (94\%) prevalence of antibodies to CMV, and $14 \%$ of the men under 30 years old had CMV viruria. ${ }^{1}$ In a Danish study the prevalence of antibodies among homosexual men was related to the duration of homosexual activity. ${ }^{2}$ CMV has also been suggested as having a role in the occurrence of the acquired immune deficiency syndrome (AIDS) and in the aetiology of Kaposi's sarcoma. ${ }^{3}$

During a study of the efficacy of a hepatitis B vaccine we recently followed a large group of homosexual men over a period of nearly two years. This gave us an opportunity to study the prevalence and incidence of infection with CMV and its relation with a number of risk factors in this group of men.

\section{Patients, materials, and methods}

\section{STUDY POPULATION}

The study population consisted of male homosexuals who had participated in an efficacy trial with a heat

Address for reprints: Dr R A Coutinho, Municipal Health Service, P O Box 20244, Amsterdam, The Netherlands

Accepted for publication 16 January 1984 inactivated hepatitis $B$ vaccine between November 1980 and December $1982 .{ }^{4}$ Men could enter this trial if they were between 16 and 50 years old, were negative for hepatitis B virus markers, had serum alanine transferase (serum ALT) activity $<50 \mathrm{IU} / 1$ (normal activity $<21 \mathrm{IU} / \mathrm{l}$ ), no serious illnesses, and had had at least two different male sexual partners in the preceding six months. Men who lived in and around Amsterdam were selected for the study of CMV.

\section{CONDUCT OF THE STUDY}

At the beginning of the study (month 0 ) the participants were questioned about their medical history and lifestyle. Age was taken in years at the time of the interview. The duration of homosexual activity was defined as the number of years from the first homosexual contact until the time of the interview. A history of syphilis was noted. Each man was asked to give an estimate of the number of different sexual partners in the six months preceding the interview. The question about anal sexual contact did not specify whether intercourse was active or passive.

Blood samples were taken at monthly intervals during the first five months and every three months thereafter. The first and last blood samples were tested for the presence of antibodies to cytomegalovirus (anti-CMV). If a seroconversion or a significant (more than fourfold) rise in titre was found, all other samples were tested for anti-CMV. 
CMV infections were defined as: primary CMV infection (seroconversion for anti-CMV in at least two sequential blood samples, confirmed by the presence of anti-CMV IgM antibodies); or recurrent CMV infection (a more than fourfold rise in titre in a man with anti-CMV (complement fixation $\geqslant 8$ ), confirmed in at least one subsequent blood sample). A man was considered to have had clinical signs of infection with CMV if he had had either viral hepatitis (serum ALT activity $\geqslant 50 \mathrm{IU} / 1$ at least once with negative serological markers for hepatitis B and A) or a mononucleosis-like illness of more than one week's duration at the time of the seroconversion or the rise in titre.

\section{LABORATORY TESTS}

Antibodies to CMV were measured by complement fixation, using $\mathrm{AD} 169$ as the antigen (Flow laboratories, Virginia, USA). An enzyme linked immunosorbent assay was used to test for IgM antibodies specific to CMV. ${ }^{5}$ Serum samples from each man were titrated simultaneously. Serum ALT activity was measured by an automated kinetic method.

\section{STATISTICAL ANALYSES}

To study the association between the prevalence of anti-CMV and potential risk factors stepwise logistic regression was used. ${ }^{6}$ The incidence of CMV during follow up was investigated with life table methods. ${ }^{7}$ Attack rates were estimated with the product limit method, and the relation to risk factors was evaluated with Cox's proportional hazards regression model. ${ }^{8}$ These statistical methods and the formulae have been described previously. ${ }^{9}$

\section{Results}

CHARACTERISTICS OF PARTICIPANTS

A total of 710 homosexual men participated in this study. Table I shows that their mean (SD) age was $30 \cdot 1(7 \cdot 0)$ years, the mean (SD) duration of their homosexual activity was $11 \cdot 0(7 \cdot 0)$ years, $35 \%$ had

TABLE I Characteristics of homosexual men participating in a study of cytomegalovirus

\begin{tabular}{lc}
\hline Characteristic & \\
\hline Number entering study & 710 \\
Mean (SD) age (years) & $30 \cdot 1(7 \cdot 0)$ \\
Mean (SD) duration of homosexual activity (years) & $11 \cdot 0(7 \cdot 0)$ \\
More than 10 different sexual partners in & \\
preceding six months (\%) & $35 \cdot 0$ \\
History of jaundice (\%) & $11 \cdot 3$ \\
History of syphilis (\%) & $18 \cdot 6$ \\
Anal sexual contact (\%) & $74 \cdot 2$ \\
Oral sexual contact (\%) & $97 \cdot 7$ \\
Hepatitis A antibodies (\%) & $40 \cdot 8$ \\
\hline
\end{tabular}

had more than 10 different sexual partners in the preceding six months, $18.6 \%$ had a history of syphilis, and $74 \cdot 2 \%$ had had anal sexual contact.

\section{INFECTIONS AMONG PARTICIPANTS}

Of the 710 participants, $501(70 \cdot 6 \%)$ were found to have complement fixing antibodies to CMV at entry to the study. A total of 69 infections with CMV were diagnosed during follow up: 50 primary infections among the 209 seronegative men and 19 recurrent infections among 501 seropositive men. Only 12 men had clinical signs of CMV infection: nine had a mononucleosis-like illness, and three had viral hepatitis. Of these $12 \mathrm{men}, 10$ had a primary and two a recurrent infection.

Figure 1 shows that at the end of the study (after 23 months) the attack rate for primary infections was $27 \cdot 3 \%$ and for recurrent infections $6 \cdot 2 \%$. As the curves climbed steadily there was no evidence of clustering of the CMV infections.

\section{ASSOCIATION BETWEEN PREVALENCE OF} ANTIBODY AND POTENTIAL RISK FACTORS

Table II shows that four characteristics of the participants' lifestyles correlated (by stepwise logistic regression) with seropositivity for $\mathrm{CMV}$. The duration of homosexual activity had the highest influence $(p<0.002)$, the probability of being seropositive
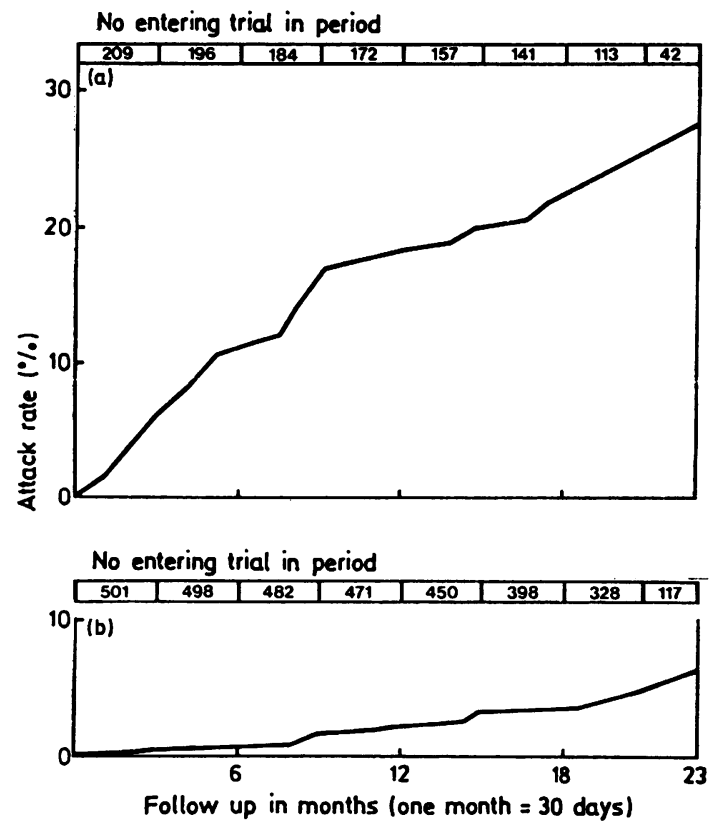

FIG 1 Life table showing the attack rates for (a) primary and (b) recurrent infections with cytomegalovirus. 
TABLE II Correlation of characteristics of lifestyles with seropositivity for cytomegalovirus in homosexual men (evaluation by stepwise logistic regression)

\begin{tabular}{lllll}
\hline Characteristic & $\begin{array}{l}\text { Co- } \\
\text { efficient } \\
(\beta)\end{array}$ & $\begin{array}{l}\text { Standard } \\
\text { error (SE) }\end{array}$ & $\beta / S E$ & $p$ value* \\
\hline $\begin{array}{l}\text { Duration of homo- } \\
\text { sexual activity }\end{array}$ & 0.047 & 0.015 & 3.20 & $<0.002$ \\
$\begin{array}{l}\text { Number of different } \\
\quad \text { sexual partners in } \\
\text { preceding six months }\end{array}$ & 0.128 & 0.058 & 2.21 & $<0.03$ \\
$\begin{array}{l}\text { History of syphilis } \\
\text { Anal sexual contact }\end{array}$ & $\begin{array}{l}0.474 \\
0.204\end{array}$ & 0.142 & 3.34 & $<0.001$ \\
Constant & 0.166 & 0.269 & 2.04 & $<0.05$ \\
\hline
\end{tabular}

*two tailed

increasing by $1-2 \%$ with each year of homosexual activity (fig 2). This effect was independent of age. The next important risk factor was the number of different sexual partners in the preceding six months $(p<0.03)$, the risk increasing with an increasing number of partners (fig 3). A history of syphilis significantly increased the odds $\mathrm{P}(+) / \mathrm{P}(-)$ by $61 \%$, and anal sexual contact by $23 \%$. Other variables such as age, oral sexual contact, and history of jaundice had no appreciable influence in this study.

\section{ASSOCIATION BETWEEN INCIDENCE OF CMV DURING FOLLOW UP AND POTENTIAL RISK FACTORS}

Table III shows that two variables correlated with the risk of contracting a primary CMV infection among the 209 antibody negative homosexual men: a history of syphilis (relative risk $2 \cdot 21$ ), and anal sexual

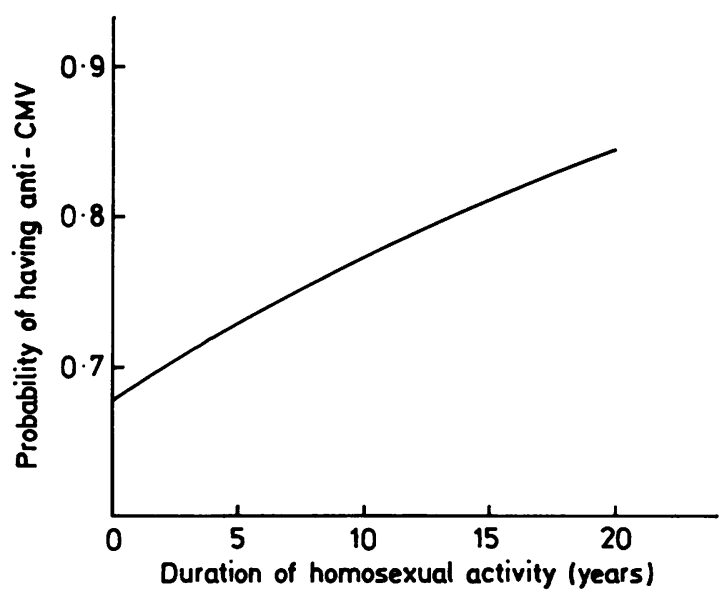

FIG 2 Correlation between duration of homosexual activity and probability of seropositivity for cytomegalovirus in 710 homosexual men. (No of sexual partners in preceding six months kept constant at 6-10, no history of syphilis, positive history of anal sexual contact.)

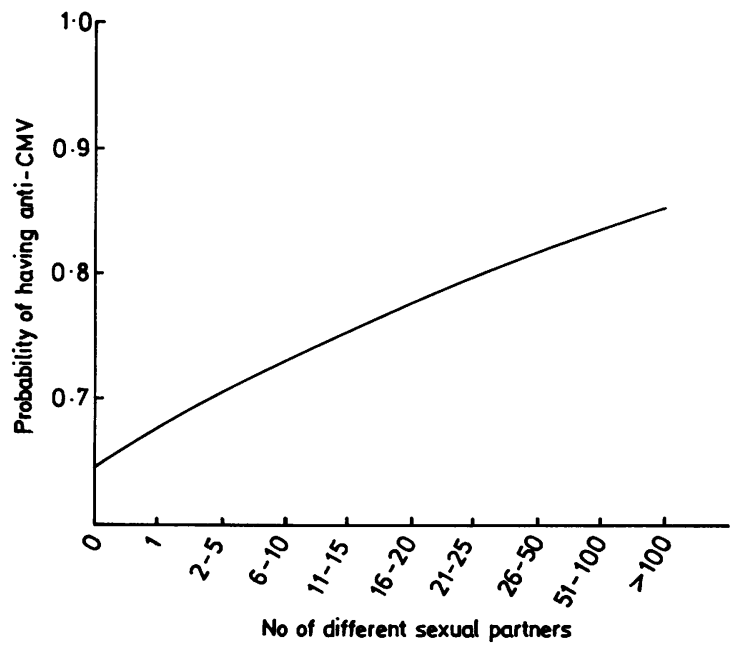

FIG 3 Correlation between number of sexual partners in preceding six months and probability of seropositivity for cytomegalovirus in 710 homosexual men. (Duration of homosexual activity kept constant at five years, no history of syphilis, positive history of anal sexual contact.)

contact (relative risk 2 49). The other characteristics of lifestyle (including the number of different sexual partners in the preceding six months) had no significant influence on the rate of primary infection with CMV.

None of the characteristics of lifestyle of the seropositive participants was found to be appreciably associated with the risk of acquiring a recurrent CMV infection during follow up.

\section{Discussion}

The prevalence of antibodies to CMV among adults in Europe and North America generally varies between $30 \%$ and $60 \%$, depending on the socioeconomic background of the population, ${ }^{10}$ with a much higher prevalence among male homosexuals in San Francisco $(94 \%)$ and Copenhagen (87\%). ${ }^{12}$ In our study of 710 homosexual men living in and around Amsterdam a

TABLE III Correlation of variables with the risk of primary cytomegalovirus infection in 209 antibody negative homosexual men (evaluation by regression with incomplete survival data)

\begin{tabular}{lllllll}
\hline Characteristic & $\begin{array}{l}\text { Co- } \\
\text { efficient } \\
(\beta)\end{array}$ & $\begin{array}{l}\text { Standard } \\
\text { error (SE) }\end{array}$ & $\beta / S E$ & pvalue* & $e^{\beta}$ \\
\hline $\begin{array}{l}\text { History of } \\
\text { syphilis }\end{array}$ & 0.793 & 0.347 & 2.29 & $<0.03$ & 2.21 \\
$\begin{array}{l}\text { Anal sexual } \\
\text { contact }\end{array}$ & 0.911 & 0.395 & 2.31 & $<0.03$ & 2.49 \\
\hline
\end{tabular}

*two tailed 
somewhat lower prevalence $\mathbf{7 1 \%}$ ) was found. The reason for this relatively low prevalence is probably the selection of the participants who were all hepatitis B marker negative. Hepatitis $B$ is sexually transmitted among homosexual men, ${ }^{11} 12$ and we therefore selected those men with a relatively short duration of homosexuality and a relatively low total number of different sexual partners.

Among the 209 seronegative men, 50 primary CMV infections were detected during follow up, the attack rate being $27 \cdot 3 \%$ at the end of the study (after 23 months). This attack rate is very high when compared with incidences in other large prospective studies among healthy adults. Stern et al followed 254 seronegative English women during pregnancy and found eight (3\%) primary CMV infections, ${ }^{13}$ and Griffith et al in a study of 1608 seronegative pregnant women found $14(0.9 \%)$ primary CMV infections. ${ }^{14}$ Among 713 seronegative English students, $10(1 \cdot 4 \%)$ seroconverted during a follow up period of seven months. ${ }^{15}$

Among the 501 seropositive men, 19 recurrent CMV infections were detected serologically during the follow up period of 23 months (attack rate $6 \cdot 2 \%$ ).

It is difficult to draw conclusions about the recurrent infections as we have only serological data, and viral cultures were not performed. The majority of recurrent CMV infections represent reactivation of latent virus, although reinfection with a new virus strain occurs occasionally. ${ }^{16}$ From a Danish study it appears that a high percentage of antibody positive homosexual men excrete CMV in their seminal fluid. ${ }^{17}$ There is therefore ample opportunity for promiscuous homosexual men to become reinfected with a new virus strain, but our serological data indicate that this may be an uncommon event.

We found that the prevalence of antibody to CMV correlated with four characteristics of the participants' lifestyle: duration of homosexual activity, number of different sexual partners in the preceding six months, history of syphilis, and anal sexual contact. Among the seronegative men, the primary incidence of infection with CMV correlated with two variables: a history of syphilis and anal sexual contact. These correlations indicate that CMV infections are sexually transmitted among homosexual men. It is not completely clear why no correlation was found in this study between the number of different sexual partners in the preceding six months and the incidence of CMV among those susceptible. This may indicate that the number of sexual partners is of less importance than anal sexual contact in the transmission of CMV. CMV is known to be present in semen ${ }^{17} 18$ and it seems likely from this study that anal sexual contact plays an important part in the transmission of CMV among this group of men. Another sexually transmitted disease among male homosexuals, hepatitis B, is also related to anal sexual contact. In a recent study of homosexual men hepatitis A was also found to be sexually transmitted but no relation was found with anal sexual contact alone, which indicates a different means of transmission (by oroanal contact). ${ }^{9}$

We conclude that CMV infections are highly prevalent among homosexual men and that anal sexual contact plays an important part in the transmission of the virus.

We thank the participants for their cooperation, and W Maruanaya, $\mathrm{J}$ van Marle, $\mathrm{N}$ Lelie, and $\mathrm{H}$ Ross for their help. This study was supported by the Dutch ministry of health and in part by the Netherlands foundation for preventive medicine (grant no 28-440).

\section{References}

1. Drew WL, Mintz L, Miner RC, Sands M, Ketterer B. Prevalence of cytomegalovirus infection in homosexual men. $J$ Infect Dis 1981; 143: 188-92.

2. Melbye M, Biggar RJ, Ebbesen $\mathbf{P}$, Andersen HK, Vestergaard BF. Lifestyle and antiviral antibody studies among homosexual men in Denmark. Acta Pathol Microbiol Scand B 1983; 91:357-64.

3. Drew WL, Miner RC, Ziegler JL, et al. Cytomegalovirus and Kaposi's sarcoma in young homosexual men. Lancet 1982; ii: $125-7$.

4. Coutinho RA, Lelie N, Albrecht-van Lent P, et al. Efficacy of a heat inactivated hepatitis $B$ vaccine in male homosexuals: outcome of a placebo controlled double blind trial. $\mathrm{Br} \mathrm{Med} J$ 1983; 286: 1305-8.

5. Loon AM van, Heessen FWA, Logt JThM van der, Veen J van der. Direct enzyme-linked immunosorbent assay that uses peroxidase-labeled antigen for determination of immunoglobulin $\mathbf{M}$ antibody to cytomegalovirus. J Clin Microbiol 1981; 13:416-22.

6. Anonymous. Biomedical data processing manual. Berkeley, California: University of California Press, 1981;303-44.

7. Kalbfleish J, Prentice RL. The statistical analysis of failure time data. New York: Wiley and Son, 1980.

8. Cox DR. The analysis of binary data. London: Methuen, 1969.

9. Coutinho RA, Lelie N, Albrecht-van Lent P, Nagelkerke N, Kuipers H, Rýsdyk T. Prevalence and incidence of hepatitis A among male homosexuals. Br Med J 1983;287: 1743-5.

10. Gold E, Nankervis GA. Cytomegalovirus. In: Evans AS, ed. Viral infections of humans. 2nd ed. New York, London: Plenum Medical Book Company, 1982: 167-86.

11. Szmuness W, Much I, Prince AM, et al. On the role of sexual behaviour in the spread of hepatitis B infection. Ann Intern Med 1975;83:489-95.

12. Schreeder MT, Thompson SE, Hadler SC, et al. Hepatitis B in homosexual men: prevalence of infection and factors related to transmission. J Infect Dis 1982;146:7-15.

13. Stern H, Tucker SM. Prospective study of cytomegalovirus infection in pregnancy. $\mathrm{Br}$ Med $J$ 1973; ii: 268-70.

14. Griffith PD, Campbell-Benzie A, Heath RB. A prospective study of primary cytomegalovirus infection in pregnant women. Br J Obstet Gynaecol 1980;87:308-14.

15. University health physicians and PHLS laboratories. Infectious mononucleosis and its relationship to EB-virus antibody. $\mathrm{Br}$ Med J 1971;iv:643-6.

16. Huang ES, Huong SM, Tegtmeier GE, Alford C. Cytomegalovirus: genetic variation of viral genomes. Ann NY Acad Sci $1980 ; 354: 332-46$.

17. Biggar RJ, Andersen HK, Ebbesen P, Melbye M, Goedert JJ Mann DL, Strong DM. Seminal fluid excretion of cytomegalovirus related to immunosuppression in homosexual men. $B$ Med $J$ 1983; 286:2010-2.

18. Lang DJ, Kummer JF. Demonstration of cytomegalovirus in semen. $N$ Engl J Med 1972;287:756-8. 